\title{
A Review on the Potential Applications of Cocoa Shell in Food Industry
}

\author{
Glynnis Netania ${ }^{1}$, Tabligh Permana ${ }^{1, *}, J$ Juli Effendy ${ }^{2}$, Filiana Santoso $^{1}$, Edrick \\ Alvaro Oslo ${ }^{1}$ \\ ${ }^{1}$ Study Program of Food Technology, Faculty of Life Sciences and Technology, Swiss German University, Indonesia \\ ${ }^{2}$ PT Indoaroma Kurnia Makmur, Indonesia \\ *Corresponding author. Email: tabligh.permana@gmail.com
}

\begin{abstract}
Cocoa shell is one of the main by-products of cocoa beans. It is separated from the nibs and are disposed of, as it could affect the final quality of cocoa products. As a result, a high amount of waste can be produced during mass production of cocoa beans. Indonesia is one of the largest producers of cocoa beans, and thus hundreds of tonnes of cocoa shells being thrown away can be expected each year. Despite being considered waste, cocoa shells are actually nutritionally dense, containing high amounts of dietary fiber and polyphenols. Using the appropriate treatment to remove the naturally occurring mycotoxins in cocoa shells, this underutilized ingredient can have economical value when incorporated into food products. Some products that are included in this review, namely corn extruded snacks, butter biscuits, cooked beef, and a functional beverage, all show an increase in polyphenols and dietary fibers when cocoa shells were added. However, the main challenge of cocoa shell application lies in the sensory acceptability of the consumers. This paper summarizes the overview of the nutritional and chemical compositions of cocoa shell and its potential application in the food industry as a functional ingredient.
\end{abstract}

Keywords: Cocoa by-products, Cocoa shell, Cocoa waste, Dietary fiber, Polyphenols.

\section{INTRODUCTION}

Indonesia is one of the largest producers of cocoa beans. Having contributed to $90 \%$ of the world's total amount of cocoa beans, it is expected that a large amount is produced each year [1]. It was recorded that in 2018 and 2019, total cocoa bean production has reached more than 700,000 tonnes per year, and it is estimated to increase in the following years [2]. However, it was discovered that around $80 \%$ of the cocoa fruit is disposed of, as they could not be used in food products $[3,4]$. One of the main by-products is cocoa shells, and they account for around $10-20 \%$ of each bean $[5,6]$. Cocoa shells are considered waste, as they could alter the final quality of cocoa products, and can cause abrasion to the equipment used in processing $[5,7,8]$. The main method of disposing of cocoa shells was mostly using them as animal feed [9, 10, 11]. However, it is a relatively uncommon practice, due to the methyl-xanthines found in cocoa shells. These chemicals have been found to be toxic when consumed by animals, and therefore not a suitable method of disposing cocoa shells [12]. Despite being considered waste, it was discovered that cocoa shells are rich in fibers and polyphenols [13, 14]. Based on the nutritive value of cocoa shells, it will open up possible applications and increase the economic value of cocoa shells. By utilizing this underused by-product, less cocoa waste will be accumulated, while also increasing options for ingredients classified as functional food. This review aims to compile existing studies on the applications of cocoa shells in the food industry as functional food.

\section{APPLICATION OF COCOA SHELLS}

The applications of cocoa shells compiled in this review are divided into fortification, as antioxidant and as a functional beverage. It is due to the chemical compositions that are present in cocoa shells, that it can be considered as a functional ingredient. 
Table 1. Chemical components of cocoa shell from different origins and treatments (g/kg dry matter) $[29,30,31,32]$

\begin{tabular}{|c|c|c|c|c|}
\hline Reference & [29] & [30] & [31] & [32] \\
\hline Origin & Spain & $\begin{array}{l}\text { Ghana, Ecuador, } \\
\text { Ivory Coast }\end{array}$ & Spain & $\begin{array}{l}\text { Cone and Taura, } \\
\text { Ecuador }\end{array}$ \\
\hline Treatment & Roasted & Not stated & Sterilized & $\begin{array}{c}\text { Dried with air tunnel } \\
\text { drier }\end{array}$ \\
\hline \multicolumn{5}{|c|}{ Chemical Components of Cacao Shell (g/kg dry matter) } \\
\hline Fat & $185 \pm 12$ & $68.1 \pm 2.5$ & $66.2 \pm 3.8$ & $20.2 \pm 0.3$ \\
\hline Protein & $116 \pm 2$ & $181.2 \pm 8.1$ & $167.1 \pm 1.8$ & $158.5 \pm 1.7$ \\
\hline Ash & $75 \pm 1$ & $81 \pm 3.9$ & $114.2 \pm 0.04$ & $73.5 \pm 1.5$ \\
\hline Fiber & $504 \pm 21$ & $606 \pm 6.4$ & $605.4 \pm 3.2$ & $567 \pm 1.1$ \\
\hline Moisture & $47 \pm 1$ & $101 . \overline{2} \pm 6$ & $\mathrm{Nd}$ & $77.1 \pm 1.2$ \\
\hline Theobromine & $\mathrm{Nd}$ & $12.9 \pm 1.8$ & $\mathrm{Nd}$ & $\mathrm{Nd}$ \\
\hline Phytic Acid & $\mathrm{Nd}$ & $5.9 \pm 0.6$ & $\mathrm{Nd}$ & $\mathrm{Nd}$ \\
\hline Polyphenols & $\mathrm{Nd}$ & $18.2 \pm 8.4$ & $57.8 \pm 2.9$ & $80.17-154.43^{*}$ \\
\hline Others & 73 & $\mathrm{Nd}$ & $\mathrm{Nd}$ & $\mathrm{Nd}$ \\
\hline
\end{tabular}

Means are express with \pm standard deviation.

$\mathrm{Nd}$ : not determined.

*in $\mathrm{mg} \mathrm{GAE} / \mathrm{g}$

\subsection{Chemical composition of cocoa shells}

It was recently found that this by-product actually contains high levels of dietary fiber and polyphenols [13, 14]. Table 1 shows that the highest chemical components are dietary fibers, and they also have a significant number of polyphenols. Due to the properties of the phenolic compounds, cocoa shells can be utilised as antioxidants $[14,15]$. It also contains similar volatile compounds and colorants to cocoa beans and its derivatives, and thus have the potential to become food additives [16].

Despite the numerous chemicals found in cocoa shells, mycotoxin levels (mainly Ochratoxin-A) are much higher in cocoa shells than in any other cocoa byproduct [17]. These toxins are very dangerous when consumed at a large amount, which further emphasises the importance of mycotoxin removal during cocoa shell processing.

\subsection{Pre-treatment of cocoa shells}

Ochratoxin-A is a mycotoxin that can be found in cocoa shells, and are most commonly formed by Aspergillus fungi [17]. The pre-treatment is necessary, as ochratoxin-A are considered as carcinogenic, and are also thermally-stable substances, which makes them resist most processes that involve heat [17].

An effective method of removal involves the extraction of ochratoxin-A from cocoa shells using an aqueous solution of $2 \%$ Potassium Carbonate $\left(\mathrm{K}_{2} \mathrm{CO}_{3}\right)$, at $90{ }^{\circ} \mathrm{C}, 1,000 \mathrm{lb} / \mathrm{in}^{2}$ for 10 minutes [18]. It was observed that $98 \%$ of Ochratoxin-A in the cocoa shells can be removed using this method. Not only due to its ability to remove ochratoxin-A, it also takes little time to conduct, and the salt used is safe for consumption. Therefore, it is the most optimum pre-treatment method to remove mycotoxins in cocoa shells.

\subsection{Application of cocoa shells in fortification}

Based on the references gathered, certain changes can be tied together, as most of the results are very similar. In fortification, the cocoa shells were added to the products to increase the amounts of dietary fibers and phenolic compounds. In the application of cocoa shells in corn extruded snacks, cocoa shells were grinded and added to the corn grits before extrusion. Higher numbers of phenolic compounds can be observed, as the number of cocoa shells were increased, shown in Figure 1 [19]. However, an increase in fiber content was expected to be the cause of an increase in hardness and fracturability, shown in Figure 2.

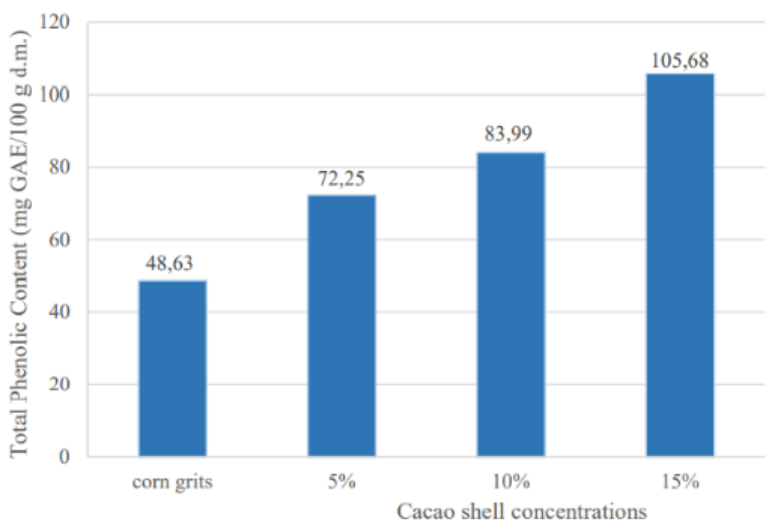

Figure 1. Total phenolic content of corn extruded snacks with cocoa shell fortification [19] 

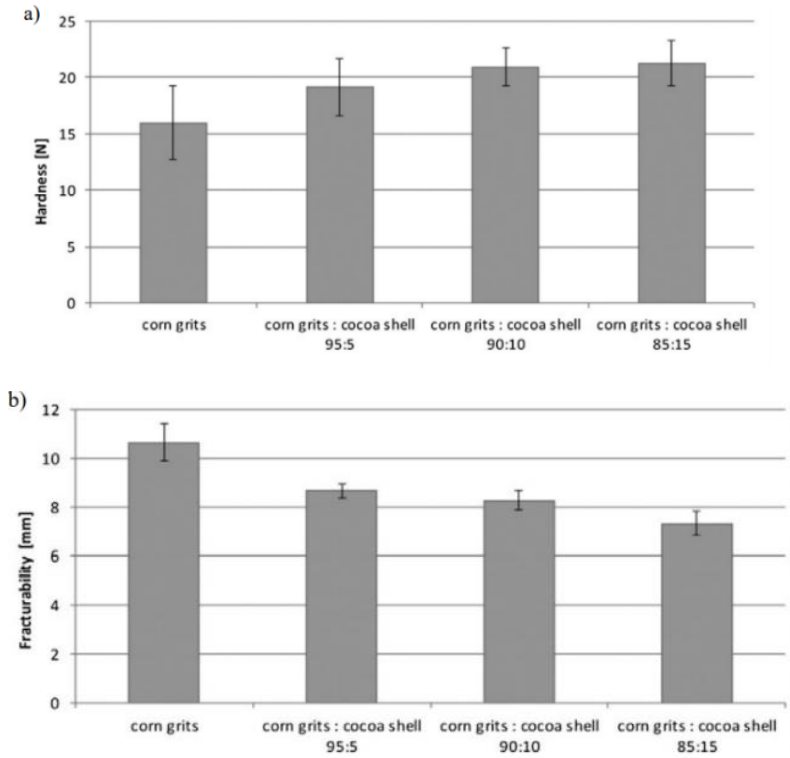

Figure 2. a) Hardness, and b) fracturability of corn extruded snacks with cocoa shell fortification [19]

Similar results can be observed in the research of the application of cocoa shells in butter biscuits [20]. Cocoa shells were grinded to powder, and added to the wheat flour. There is an increase in dietary fiber, which was expected to cause an increase in hardness of the biscuits, as shown in Table $2 \&$ Figure 3. Therefore, it can be seen from both products that cocoa shells can increase total dietary fiber and phenolic content.

Table 2. Dietary fiber content in cocoa shell fortifiedbutter biscuits [20]

\begin{tabular}{cc}
\hline \% Cocoa Shell Added & $\begin{array}{c}\text { Total Dietary Fiber } \\
(\mathbf{g} / \mathbf{1 0 0 g})\end{array}$ \\
\hline 0 & 2.9 \\
2.5 & 3.16 \\
5 & 3.58 \\
7.5 & 3.94 \\
10 & 4.22 \\
\hline
\end{tabular}

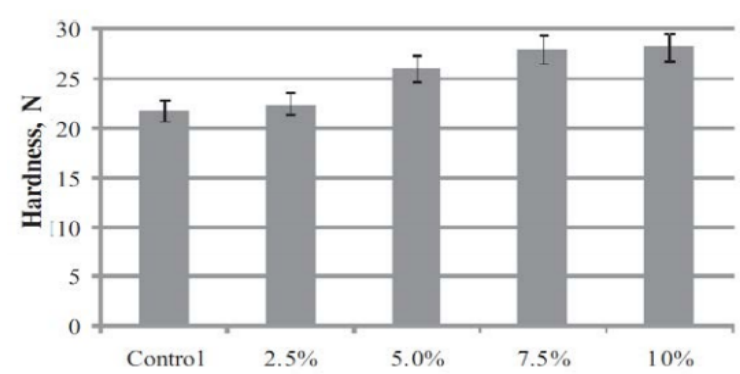

Figure 3. Hardness of cocoa shell fortified-butter biscuits [20]

\subsection{Application of cocoa shells as Antioxidant}

In lipid-based products and products rich in lipids, the addition of phenolic compounds helps with lipid oxidation stability. In a study on the application of cocoa shells in cooked beef, conducted by Ismail \& Lye Yee [21], the incorporation of cocoa shells helps in reducing the thiobarbituric acid numbers (TBA numbers), which indicates a lower rate of lipid oxidation. The experiment was conducted using cocoa shell extract, extracted using ethanol, mixed into ground beef. The beef was then cooked in a water bath and stored at $4^{\circ} \mathrm{C}$ for 14 days. Results were compared with cooked beef treated with butylated hydroxytoluene (BHT), $\beta$-tocopherol and a control group, and Figure 4 shows that natural phenolic extract obtained from cocoa shells provides better lipid oxidation stability than synthetic antioxidants $[22,23$, 24].

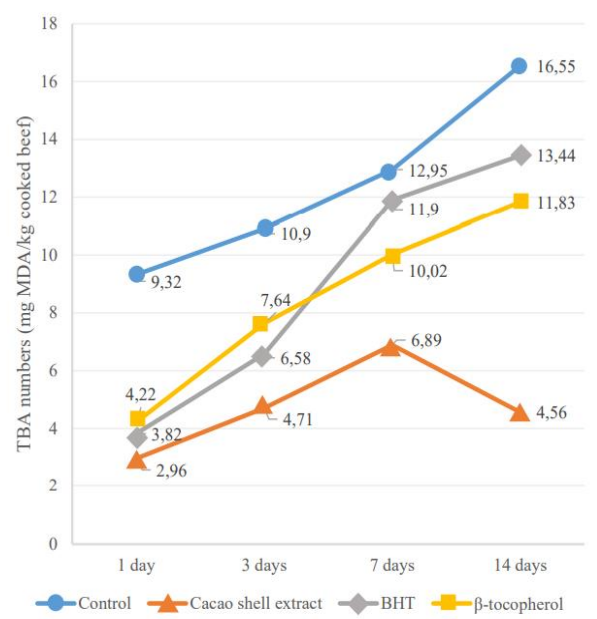

Figure 4. Lipid oxidation on cooked beef with application of cocoa shell as antioxidants [21]

Assessment of the antioxidative properties of cocoa shell extract were conducted on soy oil [25]. The oil was enriched with polyphenol extract obtained from cocoa shells, and lipid oxidation stability was measured through the free fatty acids released and the peroxide index. Extract concentrations of $0.02 \%$ and $0.04 \%$ were tested and compared with a control group (Table 3 ).

Table 3. Free fatty acids and peroxide index value of soy oil with application polyphenol extract from cocoa shell after 20 times frying treatment [25]

\begin{tabular}{ccc}
\hline $\begin{array}{c}\text { Polyphenol extract } \\
\text { concentration }(\boldsymbol{\%})\end{array}$ & $\begin{array}{c}\text { Free Fatty } \\
\text { Acids }(\boldsymbol{\%})\end{array}$ & $\begin{array}{c}\text { Peroxide Index } \\
\text { (meq O } / \mathbf{k g})\end{array}$ \\
\hline 0.00 & 0.126 & 12.843 \\
0.02 & 0.083 & 8.356 \\
0.04 & 0.073 & 6.887 \\
\hline
\end{tabular}

The oils were then used for frying for up to 20 times, and brought up to $180{ }^{\circ} \mathrm{C}$. The free fatty acids and the peroxide index were then measured, as shown in Table 3. It can be seen that as the number of cocoa shells are increased, the lower the amount of free fatty acids. This shows that by adding polyphenol extract from cocoa shells can provide antioxidative properties to lipid-based products. 


\subsection{Application of Cocoa Shells as Raw Ingredient in a Functional Beverage}

The utilization of cocoa shells as a functional beverage was evaluated [26]. Ground cocoa shells of different particle sizes were brewed using various methods of extraction. The total phenolic content of each brewing method and particle sizes were measured, and sensory analysis was conducted on 20 panellists. It was observed that particle size is correlated with the total phenolic content. The smaller the particle size, the larger the total phenolic content, as shown in Figure 5.

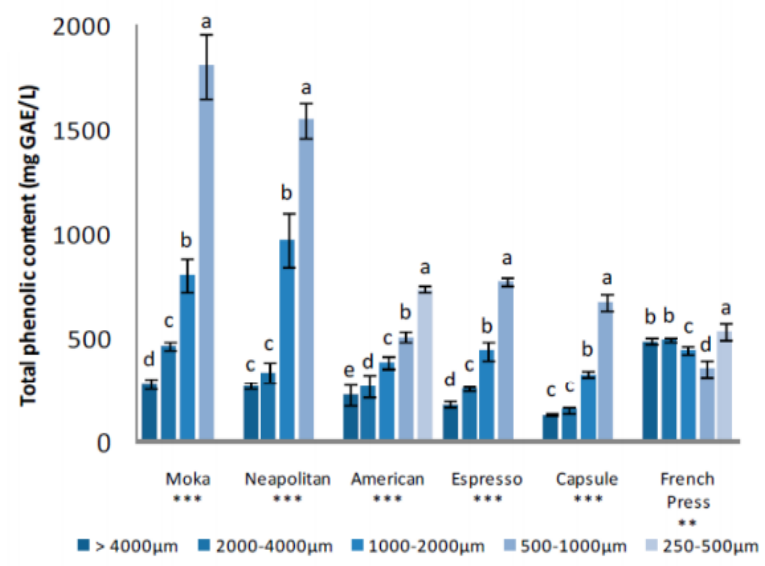

$* * *$ different letters show significant different of mean at $\mathrm{p}<0.05$

Figure 5. Total phenolic content of cocoa shell functional beverage of different particle sizes and brewing methods [26]

Results of sensory analysis using a 9-point Hedonic scale is shown on Table 4, and it shows that the decrease in particle sizes yielded lower scores. This was suspected to be caused by the higher amount of phenolic content, which are identified by astringency and bitterness [27, 28].

Table 4. Taste acceptability scores of cocoa shell functional beverage of different particle sizes [26]

\begin{tabular}{cc}
\hline Particle Size & Acceptability Score* \\
\hline$>4 \mathrm{~mm}$ & $482.5^{\mathrm{a}}$ \\
$2-4 \mathrm{~mm}$ & $335.0^{\mathrm{ab}}$ \\
$1-2 \mathrm{~mm}$ & $206.0^{\mathrm{bc}}$ \\
$0.5-1 \mathrm{~mm}$ & $152.5^{\mathrm{c}}$ \\
$0.25-0.5 \mathrm{~mm}$ & $\mathrm{n} / \mathrm{a}$ \\
\hline
\end{tabular}

*different letters in the same column show significant different of mean at $\mathrm{p}<0.05$

\section{CONCLUSION}

Cocoa shells have the potential to be utilised in the food industry as a means of reducing waste, while also providing beneficial nutrients to existing food products. Not only does it act as a rich source of fibre and phenolic compounds, but also as an antioxidant to provide oxidation stability to lipid-based products. It should be noted that the mycotoxins present in cocoa shells can be removed using aqueous 2\% Potassium Carbonate solution at $90^{\circ} \mathrm{C}, 1,000 \mathrm{lb}$./in ${ }^{2}$ for 10 minutes, in order to ensure the quality and safety of the food products.

\section{REFERENCES}

[1] Okiyama, D. C. G., Navarro, S. L. B., \& Rodrigues, C. E. C., Cocoa shell and its compounds: Applications in the food industry, Trends in Food Science and Technology, 63, 2017, pp. 103-112. DOI: https://doi.org/10.1016/j.tifs.2017.03.007

[2] Direktorat Jenderal Perkebunan Indonesia, Produksi Kakao Menurut Provinsi di Indonesia, 2015-2019 Cocoa Production by Province in Indonesia, 20152019, 2019

[3] Haydeé, K., Figueroa, N., Viridiana, N., \& García, M., Cocoa By-products, 2020, pp. 373-411.

[4] Oddoye, E. O. K., Agyente-Badu, C. K., \& GyeduAkoto, E., Cocoa and Its By-Products: Edentification and Utilization, Chocolate in Health and Nutrition, 2013, pp. 1-553. DOI: https://doi.org/10.1007/978-1-61779-803-0

[5] Belitz, H.-D., Grosch, W., \& Schieberle, P., Coffee, tea, cocoa. Food Chemistry, 938-970, 2009.

[6] Hashimoto, J. C., Lima, J. C., Celeghini, R. M. S., Nogueira, A. B., Efraim, P., Poppi, R. J., \& Pallone, J. A. L., Quality Control of Commercial Cocoa Beans (Theobroma cocoa L.) by Near-infrared Spectroscopy, Food Analytical Methods, 11(5), 2018, pp. 1510-1517. DOI: https://doi.org/10.1007/s12161-017-1137-2

[7] Kamphuis, H. J., Production of cocoa mass, cocoa butter and cocoa powder, Beckett's Industrial Chocolate Manufacture and Use, 2017, pp. 50-71.

[8] Quelal-Vásconez, M. A., Lerma-García, M. J., Pérez-Esteve, É., Arnau-Bonachera, A., Barat, J. M., \& Talens, P., Fast detection of cocoa shell in cocoa powders by near infrared spectroscopy and multivariate analysis. Food Control, 99, 2019, pp. $68-72$.

DOI: https://doi.org/10.1016/j.foodcont.2018.12.028

[9] Adeyemo, G., Ajayi, A., Longe, O., \& Olubamiwa, O., Gut Morphology and Internal Organs of Broiler Birds Fed Graded Levels of Bio-Detheobrominized Cocoa Bean Shell (CBS) Based Diets. American Journal of Experimental Agriculture, 5(2), 2015, pp. 172-177. DOI: https://doi.org/10.9734/ajea/2015/10582 
[10] Adeyemo, G., Ajayi, A., \& Olubamiwa, O., Performance of Broilers Fed Graded Levels of BioDetheobrominized Cocoa Bean Shell (CBS) Based Diets. American Journal of Experimental Agriculture, 5(6), 2015, pp. 540-545. DOI: https://doi.org/10.9734/ajea/2015/10581

[11] Emiola, I. A., Ojebiyi, O. O., \& Akande, T. O., Performance and organ weights of laying hens fed diets containing graded levels of sun-dried cocoa bean shell (CBS). International Journal of Poultry Science, 10(12), 2011, pp. 986-989. DOI: https://doi.org/10.3923/ijps.2011.987.990

[12] Adamafio, N. A., Theobromine toxicity and remediation of cocoa by-products: An overview. Journal of Biological Sciences, 13(7), 2013, pp. $570-576$

[13] Martín-Cabrejas, M. A., Valiente, C., Esteban, R. M., Mollá, E., \& Waldron, K., Cocoa hull: A potential source of dietary fibre, Journal of the Science of Food and Agriculture, 66(3), 1994, pp. 307-311.

DOI: https://doi.org/10.1002/jsfa.2740660307

[14] Miller, K. B., Stuart, D. A., Smith, N. L., Lee, C. Y., Mchale, N. L., Flanagan, J. A., Boxin, O. U., \& Hurst, W. J., Antioxidant activity and polyphenol and procyanidin contents of selected commercially available cocoa-containing and chocolate products in the United States. Journal of Agricultural and Food Chemistry, 54(11), 2006, pp. 4062-4068. DOI: https://doi.org/10.1021/jf060290o

[15] Counet, C., \& Collin, S., Effect of the Number of Flavanol Units on the Antioxidant Activity of Procyanidin Fractions Isolated from Chocolate. Journal of Agricultural and Food Chemistry, 51(23), 2003, pp. 6816-6822. DOI: https://doi.org/10.1021/jf030349g

[16] Barbosa-Pereira, L., Rojo-Poveda, O., Ferrocino, I., Giordano, M., \& Zeppa, G., Assessment of volatile fingerprint by HS-SPME/GC-qMS and E-nose for the classification of cocoa bean shells using chemometrics. Food Research International, 123(May), 2019, pp. 684-696. DOI: https://doi.org/10.1016/j.foodres.2019.05.041

[17] Copetti, M. V., Iamanaka, B. T., Nester, M. A., Efraim, P., \& Taniwaki, M. H., Occurrence of ochratoxin A in cocoa by-products and determination of its reduction during chocolate manufacture. Food Chemistry, 136(1), 2013, pp. 100-104. DOI: https://doi.org/10.1016/j.foodchem.2012.07.093

[18] Amézqueta, S., González-Peñas, E., Lizarraga, T., Murillo-Arbizu, M., \& López De Cerain, A., A simple chemical method reduces ochratoxin $\mathrm{A}$ in contaminated cocoa shells. Journal of Food Protection, 71(7), 2008, pp. 1422-1426. DOI: https://doi.org/10.4315/0362-028X-71.7.1422

[19] Jozinović, A., Panak Balentić, J., Ačkar, Đ., Babić, J., Pajin, B., Miličević, B., Guberac, S., Vrdoljak, A., \& Šubarić, D., Cocoa husk application in the enrichment of extruded snack products, Journal of Food Processing and Preservation, 43(2), 2019, pp. 1-9. DOI: https://doi.org/10.1111/jfpp.13866

[20] Karklina, D., Gedrovica, I., Reca, M., \& Kronberga, M., Production of biscuits with higher nutritional value, Proceedings of the Latvian Academy of Sciences, Section B: Natural, Exact, and Applied Sciences, 66(3), 2012, pp. 113-116. DOI: https://doi.org/10.2478/v10046-012-0005-0

[21] Ismail A. and Lye Yee C., Antioxidative Effects of Extracts of Cocoa Shell, Roselle Seeds and a Combination of Both Extracts on the Susceptibility of Cooked Beef to Lipid Oxidation, Journal of Food Technology, 4, 2006, pp. 10-15.

[22] Che Man, Y. B., \& Tan, C. P., Effects of natural and synthetic antioxidants on changes in refined, bleached, and deodorized palm olein during deepfat frying of potato chips. JAOCS, Journal of the American Oil Chemists' Society, 76(3), (1999), pp. 331-339. DOI: https://doi.org/10.1007/s11746-9990240-y

[23] Formanek, Z., Kerry, J. P., Higgins, F. M., Buckley, D. J., Morrissey, P. A., \& Farkas, J., Addition of synthetic and natural antioxidants to $\alpha$-tocopheryl acetate supplemented beef patties: Effects of antioxidants and packaging on lipid oxidation. Meat Science, 58(4), 2001, pp. 337-341. DOI: https://doi.org/10.1016/S0309- 1740(00)00149-2

[24] He, Y., \& Shahidi, F., Antioxidant Activity of Green Tea and Its Catechins in a Fish Meat Model System, 1997, pp. 4262-4266.

[25] Manzano, P., Hernández, J., Quijano-Avilés, M., Barragán, A., Chóez-Guaranda, I., Viteri, R., \& Valle, O., Polyphenols extracted from Theobroma cocoa waste and its utility as antioxidant, Emirates Journal of Food and Agriculture, 29(1), 2017, pp. 45-50. DOI: https://doi.org/10.9755/ejfa.2016-04$\underline{388}$

[26] Rojo-Poveda, O., Barbosa-Pereira, L., MateusReguengo, L., Bertolino, M., Stévigny, C., \& Zeppa, G., Effects of particle size and extraction methods on cocoa bean shell functional beverage, Nutrients, 11(4), 2019, pp. 1-19. DOI: https://doi.org/10.3390/nu11040867 
[27] Bonvehi, J. S., \& Coll, F. V., Evaluation of bitterness and astringency of polyphenolic compounds in cocoa powder. Food Chemistry, 60(3), 1997, pp. 365-370.

[28] Luna, F., Crouzillat, D., Cirou, L., \& Bucheli, P., Chemical composition and flavor of Ecuadorian cocoa liquor, Journal of Agricultural and Food Chemistry, 50(12), 2002, pp. 3527-3532.

[29] Martín-Cabrejas, M. A., Valiente, C., Esteban, R. M., Mollá, E., \& Waldron, K., Cocoa hull: A potential source of dietary fibre, Journal of the Science of Food and Agriculture, 66(3), 1994, pp. 307-311.

DOI: https://doi.org/10.1002/jsfa.2740660307

[30] Arlorio, M., Coisson, J. D., Restani, P., \& Martelli, A., Characterization of pectins and some secondary compounds from Theobroma cacao hulls, Journal of Food Science, 66(5), 2001, pp. 653-656. DOI: https://doi.org/10.1111/j.1365-621.2001.tb04616.x

[31] Lecumberri, E., Mateos, R., Izquierdo-Pulido, M., Rupérez, P., Goya, L., \& Bravo, L., Dietary fibre composition, antioxidant capacity and physicochemical properties of a fibre-rich product from cocoa (Theobroma cacao L.), Food Chemistry, 104(3), 2007, pp. 948-954. DOI: https://doi.org/10.1016/j.foodchem.2006.12.054

[32] Martínez, R., Torres, P., Meneses, M. A., Figueroa, J. G., Pérez-Álvarez, J. A., \& Viuda-Martos, M., Chemical, technological and in vitro antioxidant properties of cocoa (Theobroma cacao L.) coproducts, Food Research International, 49(1), 2012, pp. 39-45.

DOI:

https://doi.org/10.1016/j.foodres.2012.08.005 